Vol. 2, No. 2, 2020

https://doi.org/10.23939/jtbp2020.02.042

Volodymyr Hidei ${ }^{1}$, Iurii Sidun ${ }^{1}$, Oleksii Hunyak ${ }^{1}$, Svitlana Stanchak ${ }^{2}$ and Volodymyr Bidos ${ }^{1}$

\title{
APPLICATION OF WASTEPAPER SLUDGE ASH AS MINERAL POWDER FOR HOT ASPHALT CONCRETE MIX
}

\author{
Lviv Polytechnic National University, \\ ${ }^{I}$ Department of Highways and Bridges, \\ gideivolodymyr@gmail.com \\ ${ }^{2}$ College of National Army Academy named after, \\ Hetman P. Sahaidachnyi
}

(C) Hidei V., Sidun Iu., Hunyak O., Stanchak S., Bidos V., 2020

In this article the potentiality is proven for application of wastepaper sludge ash (WSA) as mineral powder for traditional hot asphalt concrete mix. For the comparative testing in this article the traditional limestone mineral powder is used. The chemical (oxide) composition of the aggregates was studied, while that was determined by means of DRON - 3.0 diffractometer. It was ascertained that $\mathrm{CaO}$ is present in wastepaper sludge ash in sufficient quantity, while it provides for utilization of this waste material as an aggregate for asphalt concrete. The limestone mineral powder granulometric composition was determined and the wastepaper sludge ash was grinded by ball grinder till the appropriate granulometric composition was reached. There were studied the main physical and mechanical parameters of bitumen 70/100 to be used for formation of asphalt binder in combination with the studied mineral aggregate. There were formed the following series of traditional hot asphalt concrete mix: on limestone mineral powder, on wastepaper sludge ash, on both limestone mineral powder and wastepaper sludge ash in ratio 50/50, 30/70, 20/80 (\% w/w). By means of grading curves of dense-graded continuous mixes there was designed the chip-grain carcass of asphalt concrete mix. The asphalt concrete mix was designed based on the following characteristics: hot fine-grained densegraded asphalt concrete with residual porosity from 2 to $5 \%$, with quantity of chip-grains sized more than $5 \mathrm{~mm}-35-45 \%$ and the maximum grain-size up to $15 \mathrm{~mm}$. There was determined that WSA can perform as material to be used as mineral powder for asphalt concrete mixes. According to the requirements of Ukrainian standard (DSTU B V.2.7-119:2011), the asphalt concrete with WSA is of standard condition, but the water-saturation index approaches the acceptably allowed value, while in comparison with asphalt concrete with LMP - it is higher by $55 \%$. Such result is due to the difference in oxide composition of the aggregates, namely lower content of products of calcareous rock in WSA. With combined application of limestone mineral powder and WSA in ratio 50/50, 30/70, 20/80 (\% w/w) the water-saturation index decreases. As to the compression tensile strength and compression tensile strength after water-saturation, these indices on WSA are lower than on LMP just by $10 \%$. The most efficient usage of WSA, considering the studies done, can be achieved when coupled with LMP in ratio 50/50.

Key words: wastepaper sludge ash (WSA), limestone mineral powder (LMP), bitumen, hot asphalt concrete.

\section{Introduction}

At present time the most wide-spread trends for paper-production waste disposal are burial, sludge composting and incineration. Still, the most ecologically and economically attractive is usage of such waste materials in various construction composites (Bajpai, 2015). One of the forward-looking waste materials (suitable for application in the construction industry) is wastepaper savings (Frias, 2015; Segui, 2015; Ferreiro, 2013). In (Ahmad, 2013) there is stated that thermoactivated wastepaper sludge ash 
(WSA) (received due to wastepaper savings incineration) possesses the binding properties and form the solidifying systems. The forward-looking is their practical application taking into account their specific structural-mechanical properties - when they are performing the role of the additional cementing materials in composite Portland-cements, mortars and dry pack mortars. Still, the review of literature has shown that the application of such approach to asphalt concrete intended for pavement of motor-roads' courses is not studied (Rahman, 2020; Pasandín, 2016; Mohammadinia, 2017).

It is generally accepted that to receive the popular type of asphalt concrete for pavement of top courses (that is, stone mastic asphalt) there is used the special stabilizing additive, which (as a rule) is produced from cellulose fiber. Still, the content of this stabilizer constitutes just about $0.3-0.5 \% \mathrm{w} / \mathrm{w}$ relative to asphalt concrete. In their turn, the authors of this article proposed to use WSA as mineral powder for classical asphalt concrete. The mineral powder is more expensive than other mineral components of asphalt concrete - chips and sand (screenings), but it performs the important functions in asphalt concrete. That is: due to availability of large specific surface area (where the part of mineral powder is counted for by $90-95 \%$ of the total surface of aggregate that comprise the asphalt concrete), the mineral powder facilitates the increase of number of contacts among the cross-linking components of asphalt concrete, fills the small voids among the larger asphalt concrete particles and have the ability to transform bitumen from volumetric state into membranous, thus creating (along with the bitumen) the asphalt binder. As a mineral powder for asphalt concrete there is traditionally used the crushed calcareous rock. As shown in (Goncharenko, 2008; Goncharenko, 2006), the activity and strength of adhesion of mineral materials with bitumen is connected with the content of oxides (cations) of alkaline, alki-earth and heavy metals. As by the influence of mineral composition of the powders upon their activity, the powders are subdivided into four groups. Attributed to the first group are the powders having high positive potential and large amount of adsorption centers in a form of cations $\mathrm{Ca}_{2}+\mathrm{i} \mathrm{Mg}_{2}+$ (calcite, limestone, dolomite). Attributed to the second group are the powders whose grains' surface has negative charge with large amount of adsorption centers in a form of ions O2- (quartz, kaolin, granite, silicone). Attributed to the third group are the powders having lowered negative potential, with presence on the particles' surface of the compensating cations of various valency $\mathrm{K}+, \mathrm{Na}+, \mathrm{Ca}_{2}+, \mathrm{Mg}_{2}+$ (mica, asbestos, gabbro, feldspar etc.). Attributed to the forth group are the powders having neutral surface (talc, graphite etc.). Taking into account the above mentioned, to apply this or that industrial waste material as a mineral powder for asphalt concrete - it shall possess the appropriate granulometric, chemical and mineralogical composition.

\section{Target of this article}

To determine the quantitative and qualitative influence of WSA upon the properties of hot asphalt concrete.

\section{Techniques used}

For the comparative testing there were chosen two aggregates for asphalt concrete: WSA of PJSC "Kyiv Cardboard and Paper Mill" and limestone mineral powder (LMP) produced by "Skala-Podilskii Spetscarier (Special Quarry)".

In Table 1 there is presented the chemical (oxide) composition of aggregates, which was determined by means of DRON - 3.0 diffractometer.

The analysis of Table 1 witnesses, that present in the WSA composition there is $\mathrm{CaO}$ (being the product of $\mathrm{CaCO}_{3}$ roasting) in the sufficient quantity, while that indicates on the potentiality of using this waste material as an aggregate for asphalt concrete.

WSA consists of the particles sized nearly $10 \mathrm{~mm}$. Therefore, it was grinded by means of ball grinder till the standard sizes, by which the high-quality mineral powder is characterized (please, see Table 2). 
Chemical composition of aggregates

\begin{tabular}{|c|c|c|c|c|c|c|c|c|}
\hline $\begin{array}{c}\text { Name of the } \\
\text { aggregate }\end{array}$ & \multicolumn{7}{|c|}{ Name of element, \% w/w } & $\sum$ \\
\hline \multirow{2}{*}{ WSA } & $\mathrm{SiO}_{2}$ & $\mathrm{Al}_{2} \mathrm{O}_{3}$ & $\mathrm{Fe}_{2} \mathrm{O}_{3}$ & $\mathrm{CaO}$ & $\mathrm{MgO}$ & $\mathrm{SO}_{3}$ & LOI & \multirow{2}{*}{100.0} \\
& 26.44 & 15.36 & 1.16 & 49,84 & 2.16 & 0.45 & 4.59 & \\
\hline $\begin{array}{c}\text { Limestone } \\
\text { mineral powder }\end{array}$ & $\mathrm{SiO}_{2}$ & $\mathrm{Al}_{2} \mathrm{O}_{3}$ & $\mathrm{Fe}_{2} \mathrm{O}_{3}$ & $\mathrm{CaCO}_{3}$ & $\mathrm{MgCO}_{3}$ & - & 1.0 & 100.0 \\
\hline
\end{tabular}

Table 2

\section{Granulometric composition of the mineral powder and WSA}

\begin{tabular}{|c|c|c|c|c|c|c|c|}
\hline \multirow{2}{*}{ Name of the aggregate } & \multicolumn{6}{|c|}{ Sieves, particle residue on the sieve, $\% \mathrm{w} / \mathrm{w}$} & \multirow{2}{*}{$\sum$} \\
\hline & 1.25 & 0.63 & 0.315 & 0.14 & 0.071 & $<0.071$ & \\
\hline WSA & 0.2 & 0.4 & 1.2 & 8.8 & 7.4 & 82.0 & 100 \\
\hline Limestone mineral powder & 0 & 0.1 & 1.2 & 4.7 & 12.9 & 81.1 & 100 \\
\hline
\end{tabular}

As initial bitumen for asphalt concrete there was used crude-oil heavy pavement oxidized bitumen grade 70/100 from JSC Mozyr Refinery, Belarus, Gomel Region, town of Mozyr. The operation characteristics of taken bitumen are presented in Table 3. As per the tested indices, the present bitumen corresponds to the grade 70/100 according to (EN 12591; DSTU 4044). Also to produce asphalt concrete mixes there were used broken stone $10-15,5-10 \mathrm{~mm}$ and chips screenings $0-5 \mathrm{~mm}$ (granite quarry JSC "Polonskiy Gorniy Combinat").

Table 3

Main physical and mechanical parameters of bitumen 70/100

\begin{tabular}{|l|c|}
\hline \multicolumn{1}{|c|}{ Index } & Values \\
\hline Penetration at $25^{\circ} \mathrm{C}, \mathrm{M} \cdot 10^{-4}(0.1 \mathrm{~mm})$ & 83 \\
\hline Softening point, ${ }^{\circ} \mathrm{C}$ & 50 \\
\hline Ductility at $25^{\circ} \mathrm{C}, \mathrm{M} \cdot 10^{-2}(\mathrm{~cm})$ & $>100$ \\
\hline
\end{tabular}

To achieve the purpose of testing there were formed the various series of the traditional hot asphalt concrete mix according to Table 4: on limestone mineral powder, on WSA, on both limestone mineral powder and WSA in ratio 50/50, 30/70, 20/80 (\% w/w). By means of grading curves of dense-graded continuous mixes there was designed the chip-grain carcass of asphalt concrete mix. The asphalt concrete mix was designed based on the following characteristics: hot fine-grained dense-graded asphalt concrete with residual void content from 2 to $5 \%$, with quantity of chip-grains sized more than $5 \mathrm{~mm}-35-45 \%$ and the maximum grain-size up to $15 \mathrm{~mm}$ (Table 4).

Table 4

Asphalt concrete composition

\begin{tabular}{|c|c|}
\hline Name of material & Content of material in asphalt concrete, $\%$ \\
\hline Broken stone $15-10 \mathrm{~mm}$ & 5.0 \\
\hline Broken stone $10-5 \mathrm{~mm}$ & 35.0 \\
\hline Chips screenings, grade $5-0.63 \mathrm{~mm}$ & 32.0 \\
\hline Chips screenings, grade $0.63-0.071 \mathrm{~mm}$ & 17.0 \\
\hline Mineral powder & 11.0 \\
\hline Total quantity, $\%$ & 100.0 \\
\hline Bitumen $70 / 100$ & 6.25 \\
\hline
\end{tabular}


Physical-mechanical properties of asphalt concrete of various series are presented in Table 5. The asphalt concrete indices are accepted in accordance with (DSTU B V.2.7-119:2011) for the climate area of West Ukraine (Lviv Region).

Table 5

Physical-mechanical properties of asphalt concrete

\begin{tabular}{|c|c|c|c|c|c|c|c|}
\hline \multirow{2}{*}{ No } & \multirow{2}{*}{ Name of index } & \multicolumn{5}{|c|}{ Asphalt concrete series, $\% \mathrm{w} / \mathrm{w}$} & \multirow{2}{*}{$\begin{array}{l}\text { Requirements to the } \\
\text { designed asphalt } \\
\text { concrete }\end{array}$} \\
\hline & & $\begin{array}{l}\text { LMP } \\
100\end{array}$ & $\begin{array}{c}\text { WSA } \\
100\end{array}$ & $\begin{array}{c}\text { LMP/WSA } \\
50 / 50\end{array}$ & $\begin{array}{c}\text { LMP/WSA } \\
30 / 70\end{array}$ & $\begin{array}{c}\text { LMP/WSA } \\
20 / 80\end{array}$ & \\
\hline 1 & Average density, $\mathrm{g} / \mathrm{cm}^{3}$ & 2.36 & 2.33 & 2.34 & 2.35 & 2.35 & - \\
\hline 2 & $\begin{array}{c}\text { Water-saturation, } \\
\% \text { by volume }\end{array}$ & 1.6 & 2.9 & 2.0 & 2.5 & 2.7 & Not more than 3.0 \\
\hline 3 & $\begin{array}{l}\text { Compression tensile } \\
\text { strength, } \mathrm{MPa} \text {, at: } \\
\qquad \begin{array}{c}{ }^{\circ} \mathrm{C} \\
50^{\circ} \mathrm{C}\end{array}\end{array}$ & $\begin{array}{l}3.8 \\
1.4\end{array}$ & $\begin{array}{l}3.5 \\
1.3\end{array}$ & $\begin{array}{l}3.6 \\
1.3\end{array}$ & $\begin{array}{l}3.5 \\
1.3\end{array}$ & $\begin{array}{l}3.5 \\
1.3\end{array}$ & $\begin{array}{c}\text { Not less than } 2.7 \\
1.3\end{array}$ \\
\hline 4 & $\begin{array}{l}\text { Compression tensile } \\
\text { strength, } \mathrm{MPa} \text {, at } 50^{\circ} \mathrm{C} \\
\text { after water-saturation }\end{array}$ & 1.2 & 1.1 & 1.2 & 1.2 & 1.2 & - \\
\hline
\end{tabular}

When making analysis of Table 5 one can ascertain that WSA may serve as a material that may be used as a mineral powder for asphalt concrete mixes. According to the requirements (DSTU B V.2.7119:2011), the asphalt concrete with WSA corresponds to the conditions, but the index of water-saturation approaches the acceptably allowed value, while in comparison with asphalt concrete with LMP it is higher by $55 \%$. Such result is caused by the difference in oxide composition of the aggregates, namely: the lower content of calcium carbonate in WSA. In conditions of combined application of limestone mineral powder and WSA in ratio 50/50, 30/70, 20/80 (\% w/w) the index of water-saturation decreases. As to compression tensile strength and compression tensile strength after water-saturation, these indices on WSA are lower than on LMP just by $10 \%$.

\section{Conclusions}

1. There was tested the chemical (oxide) composition of the aggregates and there was determined the potentiality of wastepaper sludge ash application as a mineral powder for asphalt concrete - as far as $\mathrm{CaO}$ is present in its composition in the sufficient quantity.

2. The wastepaper sludge ash was grinded till the standard (for mineral powder) granulometric composition, while the components of asphalt concrete mix were also selected and tested.

3. The traditional hot asphalt concrete compositions were designed, and the influence of wastepaper sludge ash (separately and in complex with limestone mineral powder) upon the physicaltechnical indices of asphalt concrete was tested. There was ascertained that the wastepaper sludge ash can be used as a mineral powder for asphalt concrete - both separately and in combination with mineral powder. The most efficient usage of wastepaper sludge ash (based on the testing done) can be reached in combination with LMP in ratio 50/50. 


\section{References}

Bajpai P. Management of Pulp and Paper Mill Waste / P. Bajpai. - Switzerland. Springer International Publishing, 2015. 193 p.

Frias M., Rodriguez O., Sanchez de Rojas M.I. Paper sludge, an environmentally sound alternative source of MK - based cementious materials. Contruction and Bulding Materials. 2015 vol. 74, p. 37-48. DOI:10.1016/j.conbuildmat.2014.10.007

Segui P., Aubert J. E., Husson B., Measson M. Characterization of wastepaper sludge ash for its valorization as a component of hydraulic bilders. Applied Clay Science. 2015, vol. 57, p. 79-85. DOI : 10.1016/j.clay.2012.01.007

Ferreiro S., Frias V., Vigil de la Villa R., Sanchez de Rojas M. The influence of thermo activation of art paper sludge on the technical properties of blended Portland cements. Cem. Concr. Compos., 2013, 37, $136-142$.

DOI: 10.1016/j.cemconcomp.2012.11.005

Ahmad S. Study of concrete involving use of waste paper sludge ash as partial replacement of cement / S. Ahmad, M. Iqbal Malik, M. Bashir Wani, R. Ahmad // JOSR. J. Eng. 2013. Vol. 3, No. 11. Pp. 6-15. DOI: 10.9790/3021-031130615

Rahman, M. T., Mohajerani, A., Giustozzi, F. Recycling of Waste Materials for Asphalt Concrete and Bitumen: A Review. Materials 2020, 13, 1495. DOI: 10.3390/ma13071495

Pasandín, A. R., Pérez, I., Ramírez, A.; Cano, M.M. Moisture damage resistance of hot-mix asphalt made with paper industry wastes as filler. J. Clean. Prod. 2016, 112, 853-862. DOI: 10.1016/j.jclepro.2015.06.016

Mohammadinia, A.; Arulrajah, A.; Horpibulsuk, S.; Chinkulkijniwat, A. Effect of fly ash on properties of crushed brick and reclaimed asphalt in pavement base/subbase applications. J. Hazard. Mater. 2017, 321, $547-556$. DOI: 10.1016/j.jhazmat.2016.09.039

Goncharenko E. G., Dotsenko O. M. Influence of mineral powders on asphalt-polymer binders / Collection of articles "Roads and Bridges", is. 8. K.: DerzhdorNDI, 2008. P. 68-75. (in Ukrainian).

Goncharenko E. G., Dotsenko O. M. influence of mineral powders on properties polymer asphalt concrete / Collection of articles "Roads and Bridges", is. 5. K.: DerzhdorNDI, 2006. P. 129-147. (in Ukrainian).

EN 12591:2009 Bitumen and bituminous binders. Specifications for paving grade bitumens.

Bitumens petroleum road viscous. Specifications DSTU 4044: 2019 National Standard of Ukraine. (2019). Kyiv: Ukrarkhbudinform (in Ukrainian)

Mixes asphalt concrete and asphalt concrete road and airfield. Test methods DSTU B V.2.7-319:2016 National Standard of Ukraine. (2016). Kyiv: Ukrarkhbudinform (in Ukrainian)

Mixes asphalt concrete and asphalt concrete road and airfield. Specifications. Change No. 1 DSTU B V.2.7119:2011 National Standard of Ukraine. (2011). Kyiv: Ukrarkhbudinform (in Ukrainian)

В. В. Гідей ${ }^{1}$, Ю. В. Сідун ${ }^{1}$, О. М. Гуняк ${ }^{1}$, С. А. Станчак², В. М. Бідось ${ }^{1}$ Національний університет "Львівська політехніка", ${ }^{1}$ кафедра автомобільних доріг та мостів,

${ }^{2}$ Військовий коледж сержантського складу Національної академії сухопутних військ імені гетьмана Петра Сагайдачного

\section{ВИКОРИСТАННЯ МАКУЛАТУРНОГО СКОПУ В РОЛІ МНЕРАЛЬНОГО ПОРОШКУ ДЛЯ ГАРЯЧИХ АСФАЛЬТОБЕТОННИХ СУМНШЕЙ}

(C) Гідей В. В., Сідун Ю. В., Гуняк О. М., Станчак С. А., Бідось В. М., 2020

У статті доведена можливість використання макулатурного скопу в ролі мінерального порошку для традиційного гарячого мінерального порошку. Досліджено хімічний (оксидний) склад наповнювачів, який визначили за допомогою дифлактометра ДРОН - 3.0. Встановлено, що у складі макулатурного скопу присутній СаО в достатній кількості, що дає можливість застосування цього відходу в ролі наповнювача для асфальтобетону. Встановлено зерновий склад мінерального порошку та розмелено за допомогою кульового млина до відповідного зернового складу макулатурний скоп. Досліджено основні фізико-механічні показники бітуму 70/100, що утворюватиме 3 дослідженими 
мінеральними наповнювачами асфальтне в'яжуче. Заформовано такі серії традиційної гарячої асфальтобетонної суміші з використанням: мінерального порошку, макулатурного скопу, на мінерального порошку та макулатурного скопу у співвідношенні 50/50, 30/70, 20/80 (\% мас). Встановлюємо, що макулатурний скоп може слугувати матеріалом, що можна використовувати в ролі мінерального порошка для асфальтобетонних сумішей. Згідно з вимогами ДСТУ Б В.2.7-119:2011 асфальтобетон 3 макулатурним скопом $є$ кондинційним, але показник водасичення наближається до допустимо дозволеного значення, порівняно з асфальтобетоном і з мінеральним порошком він $є$ вищим на 55 \%. Такий результат зумовлений різницею в оксидному складі наповнювачів, а саме менший вміст продуктів вапнякової породи в макулатурному скопі. За комбінованого застосування мінерального порошку та макулатурного скопу у співідношенні 50/50, 30/70, 20/80 (\% мас) показник водонасичення знижується. Щодо границі міцності при стиску та границі міцності при стиску після водонасичення зразків асфальтобетону, ці показники з використання макулатурного скопу є меншими, ніж з використанням мінерального порошку лише на 10 \%. Найраціональніше використання макулатурного скопу з огляду на проведені дослідження можна досягнути в поєднанні з мінеральним порошком у співвідношенні 50/50.

Ключові слова: макулатурний скоп, мінеральний порошок, бітум, гарячий асфальтобетон. 